\title{
Study of Composition and Composition of Macro Algae Habitat in the Intertidal Zone Water of Sibu Island, Nort Oba District Tidore Islands City Nort Maluku
}

\author{
Sukmawati Djalil ${ }^{*}$, Riyadi Subur ${ }^{1}$, Rina ${ }^{1}$, Sunarti ${ }^{1}$, Yuyun Abubakar ${ }^{1}$, Aryati H. Fadel ${ }^{1}$, Adi \\ Noman Susanto ${ }^{1}$, Sarni ${ }^{2}$ \\ ${ }^{1}$ Program Studi Manajemen Sumberdaya Perairan Fakultas Perikanan dan Kelautan Universitas Khairun Ternate \\ ${ }^{2}$ Program Studi Agroteknologi Fakultas Pertanian Universitas Khairun
}

\author{
Article History \\ Received : April 04th, 2021 \\ Revised : April $28^{\text {th }}, 2021$ \\ Accepted : May $11^{\text {th }}, 2021$ \\ Published : May $18^{\text {th }}, 2021$ \\ *Corresponding Author: \\ Sukmawati Djalil, \\ Program Studi Manajemen \\ Sumberdaya Perairan Fakultas \\ Perikanan dan Kelautan Universitas \\ Khairun Ternate, Ternate, \\ Indonesia; \\ Email: \\ djalilsukmawati@gmail.com
}

\begin{abstract}
Macro algae is a part of marine plants whose whole body is called the "thallus". Macro algae are widespread in tropical and sub-tropical waters. The purpose of this study was to determine the composition of the macro algae species, the width of the micro-habitat niches, and the overlapping of the micro-habitat niches in the intertidal zone of the waters of Sibu Island, Oba Utara District, Tidore Islands City. The data was collected using survey method using belt transects and squares measuring 1x1 $\mathrm{m} 2$ which are placed systematically in zigzags along the tansek belt. In this study, 20 species of macro algae were found in the waters of the island of Sibu, consisting of Halimeda macroloba, Halimeada opuntia forma chordata, Halimeda incrassata, Halimeda opuntia forma renschii, Chaetamorpha sp, Eucheuma cottonii, Sargassum duplicatum, S.polycestum, Turbina ornata, T. conoides, Padina boergesenii, Dictyota dichotoma, Amphiroa fragilissima, Acanthopora spicifera, Eucheuma denticulatum, E. spinosum, Glacilaria salicornia, Hypnea nidulans, Galaxaura apiculata. The results of the analysis of the width of the recesses showed that the macro algae species with the largest recess width were Eucheuma denticulatum with a value of 0.905 , while Galaxura apiculata had the narrowest recess widths with a value of 0.200 . Furthermore, based on the results of overlapping analysis of microhabitat niches, it shows that the overlap of microbaitate niches is quite large by Sargassum polycestum against Galaxaura apiculata with a value of 0.337 , while the lowest was carried out by Halimeda macroloba against Galaxaura apiculata, Halimeda opuntia forma chordata against Galaxaura apiculata with a value of 0.337 , while the lowest was carried out by Halimeda macroloba against Galaxaura apiculata, Halimeda opuntia forma chordata against Galaxaura apiculata, Eucheuma spinosum against Galaxaura apiculata with a value of 0.000 .
\end{abstract}

Keywords : Macroalgae, Species Composition, Microhabitat Niches.

\section{Pendahuluan}

Alga merupakan bagian terbesar dari tumbuhan laut yang digolongkan sebagai tumbuhan tingkat rendah karena tidak memiliki akar batang serta daun, walaupun tampak berbeda, namun secara keseluruhan struktur tubuh alga hanya terdiri dari batang yang disebut "Thallus", sehingga dimaskkan kedalam tumbuhan yang tidak berpembuluh (Trainor, 1978 ; Landau, 1992 : Yulianto, 1996)). Di Indonesia ditemukan sekitar 88 Spesis makroalga bernilai ekonomis tinggi (Tomascik et al., 1997), dari sekitar 628 jenis makro alga di temukan di Indonesia (Paloillo, 2013). Secara umum tubuh makroalga terdiri dari bagian dasar yang fungsinya menempel pada substrat yang disebut (Holdfast), dan thallus berupa percabangan.
Menurut Lobban dan Wynne (1981), makro alga terbagi atas tiga kelas berdasarkan jenis pigmen yang terkandung yakni alga merah (Rhodophyceae), alga coklat (Phaeophyceae) dan alga hijau (Cholorophyceae), selanjutnya dikatakan bahwa ketiga kelompok tersebut mempunyai peranan yang sangat besar di lingkungan laut karena peranannya sebagai prudusen primer.

Secara ekologi alga umumnya berfungsi sebagai sumber makanan dan pelindung berbagai fauna laut dan sebagai penghasil zat kapur (Bold dan Wynne, 1985 ; Duxbury dan Duxbury, 1981). Secara ekonomi dapat dijadikan sebagai bahan pangan, bahan baku industri kosmetik, dan untuk laboratorium sebagai bahan awetan basah, media berkembangbiak bagi bakteri dan jamur guna menghasilkan antibiotik, serta beberapa jenis 
makroalga dijadikan obat-obatan (Kumampung, 2006).

Habitat makroalga pada umumnya terdapat di pantai daerah intertidal dan subtidal yakni daerah diantara garis pantai sampai ke tubir (reef slope), atau biasa disebut daerah rataan terumbu (reef flats) (Kadi, 2004). Makroalga umumnya hidup di dasar laut dengan substrat berupa pasir, pecahan karang (rubble), karang mati, serta benda-benda keras yang terendam di dasar laut (Yudasmara, 2011).

Zona intertidal merupakan daerah pasang surut yang dipengaruhi oleh kegiatan daratan (pantai) dan laut. Kondisi komunitas makroalga di zona intertidal tidak banyak perubahan kecuali pada kondisi ekstrim tertentu dapat merubah komposisi dan kelimpahan organisme intertidal. Zona ini merupakan daerah yang paling sempit bila dilihat dari luasnya, namun memiliki keragaman dan kelimpahan organisme yang relatif lebih tinggi dibandingkan dengan habitat laut lainnya (Yulianda, 2013).

Relung sebagai tempat hidup suatu organisme biasanya disebut habitat. Suatu habitat adalah suatu kondisi fisik dan kemia tertentu misalnya substrat, iklim yang melengkapi satu spesies tunggal, satu kelompok spesies, atau satu komunitas (Clements \& Shelford, 1939). Sedangkan microhabitat adalah seperangkat kondisi lingkungan lokal yang lebih intim yang melengkapi suatu organisme (kendeigh, 1980; Putri 2018).

Beberepa spesies dapat menempati suatu habitat yang sama, tetapi memperlihatkan sedikit perbedaan dalam lokasinya atau mikrohabitatnya. Relung ekologi mencakup pengertian lebih luas, bukan sekedar ruang fisik atau habitat yang diduduki organisme itu, tetapi juga peranan fungsionalnya di dalam populasi atau komunitasnya seperti posisinya dalam struktur trofiknya serta posisinya di dalam perangkat kondisi lingkungan seperti gradien suhu, salinitas, $\mathrm{pH}$ dan keadaan lain dari keberadaannya (Odum, 1971; Putri, 2018 ).

\section{Bahan Dan Metode}

\section{Waktu dan Tempat}

Penelitian dilaksanakan di Perairan Pulau Sibu Kecamatan Oba Utara Kota Tidore Kepulauan Provinsi Maluku Utara. Sedangkan waktu pelaksanaan dilakukan pada bulan Desember 2019.

\section{Prosedur Pengambilan Data}

Pengambilan sampel Makroalga, dilakukan dengan menggunakan metode "Belt Transect" dan kuadrat berukuran 1 x $1 \mathrm{~m}^{2}$ (Michael, 1984). Transek ditarik tegak lurus garis pantai sepanjang 100 meter. Sketsa penempatan belt transek dan kuadrat ditampilkan pada Gabarm 2. Seluruh jenis makro alga yang ditemukan di dalam kuadrat diangkat dan dimasukkan kedalam kantong plastik berlabel untuk selanjutnya diidentifikasi dan dihitung jumlah jenis dan jumlah individu setiap spesies, yang di lakukan di laboratorium Bioekologi Fakultas Perikanan dan Kelautan Universitas Khairun.

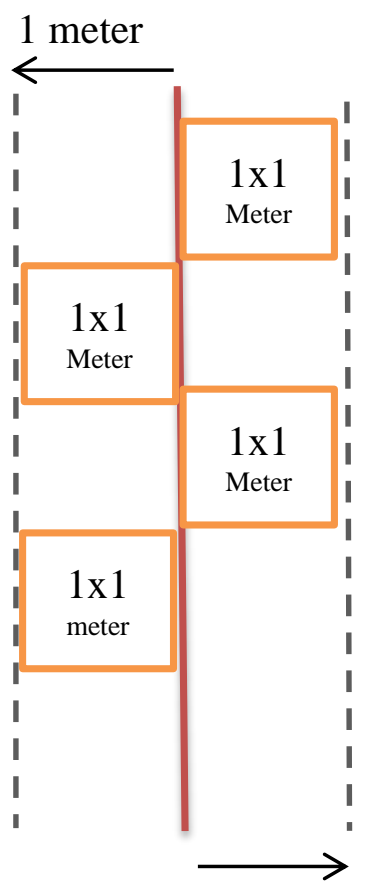

1 meter 


\section{Parameter Lingkungan}

Pengukuran parameter lingkungan dilakukan bersamaan dengan pengambilan data makroalga, pengukuran parameter lingkungan meliputi, suhu air, salinitas, dan $\mathrm{pH}$ air dilakukan pada tempat pengamatan menggunakan alat ukur HANNA Meter yang dicelupkan langsung kedalam perairan, kemudian dicatat nilai suhu air, salinitas, dan $\mathrm{pH}$ air yang tertera pada layar HANNA meter.

\section{Prosedur Analisa Data}

\section{Lebar Relung (Pianka, 1973)}

Jika sumberdaya terdistribusi secara tidak kontinyu (diskontinyu) atau dalam unit diskrit, maka lebar relung dianalisis sebagai berikut :

$$
B=\frac{1}{\sum_{i=1}^{S} p i^{2}(s)}
$$

\section{Hasil dan Pembahasan}

\section{Komposisi Jenis Makroalga}

Komposisi jenis makroalga yang ditemukan di Pulau Sibu meliputi 3 divisi yaitu (Chlorophyta, Phaeophyta, Rhodophyta), 3 kelas (Chlorophyceae, Phaeophyceae, Rhodophyceae), 7 ordo (Bryopsidales, Ulotrichales, Gigartinales, Fucales, Dictyotales, Ceramiales, Nemaliales), 9 famili (Halimedaceae, Ulotrichaceae, Solieraceae, Sargassaceae, Dictyotaceae, Rhodomelaceae, Glacilariaceae, Hypneaceae, Galaxauraceae), 12 genus (Halimeda, Chaetamorpha, Eucheuma, Sargassum, Turbinaria, Padina, Dictyota,
Dimana :

$\mathrm{Pi}=$ Proporsi spesies terdapat dalam unit ke-i dari sumberdaya dari S-unit (semua sumberdaya yang

ditemukan), sehingga $\mathrm{B}$ berkisar dari $1 / \mathrm{S}=1,0$

$\mathrm{S}=$ Jumlah microhabitat

2. Tumpah Tindih Relung (Levin, 1968)

Dimana :

$$
a_{i j}=\sum^{n} P_{i h} P_{i j}(B)
$$

$\mathrm{a}_{\mathrm{ij}} \quad=$ Kesaling-likupan/ tumpang tindih relung mikrohabitat dari jenis $\mathrm{i}$ terhadap jenis $\mathrm{j}$

$\mathrm{P}_{\mathrm{ih}} \mathrm{P}_{\mathrm{ij}}=$ Proporsi tiap jenis dalam tipe microhabitat ke-h $\mathrm{B} \quad=$ Lebar relung

Amphiroa, Acanthopora, Glacilaria, Hypnea, Galaxaura), dan 20 jenis (Halimeda macroloba, H.opuntia forma chordate, Halimeda incrassata, $H$. opuntia forma renschii, Chaetamorpha sp, Eucheuma cottonii, Sargassum duplicatum, Sargassum polycestum,Turbina ornata, Turbinaria conoides, Padina australis, Padina boergesenii, Dictyota dichotoma, Amphiroa fragilissima, Acanthhopora spicifera, Eucheuma denticulatum, Eucheuma spinosum, Glacilaria salicornia, Hypnea nidulans, Galaxaura apiculata). Untuk lebih jelas komposisi jenis makroalga yang ditemukan di Pulau Sibu ditampilkan pada Tabel 1.

\begin{tabular}{|c|c|c|c|c|c|}
\hline Divisi & Kelas & Ordo & Famili & Genus & Spesies \\
\hline \multirow[t]{5}{*}{ Chlorophyta } & Chlorophyceae & Bryopsidales & Halimedaceae & Halimeda & H. macroloba \\
\hline & & & & & H.opuntia (forma chordate) \\
\hline & & & & & H. incrassata \\
\hline & & & & & H. opuntia (forma renschii) \\
\hline & & Ulotrichales & Ulotrichaceae & Chaetamorpha & Chaetamorpha sp \\
\hline \multirow[t]{7}{*}{ Phaeophyta } & Phaeophyceae & Fucales & Sargassaceae & Sargassum & S. duplicatum \\
\hline & & & & & S. polycestum \\
\hline & & & & Turbinaria & T. ornate \\
\hline & & & & & T. conoides \\
\hline & & Dictyotales & Dictyotaceae & Dictyota & D. dichotoma \\
\hline & & & & Padina & P. australis \\
\hline & & & & & P. boergesenii \\
\hline \multirow[t]{8}{*}{ Rhodophyta } & Rhodophyceae & Ceramiales & Rhodomelacea & Amphiroa & A. fragilissima \\
\hline & & & & Acanthopora & A. spicifera \\
\hline & & Gigartinales & Soliraceae & Eucheuma & E. cottonii \\
\hline & & & & & E. denticulatum \\
\hline & & & & & E. spinosum \\
\hline & & & Glacilariaceae & Glacilaria & G. salicornia \\
\hline & & & Hypneaceae & Hypnea & H. nidulans \\
\hline & & Nemaliales & Galaxauraceae & Galaxura & G. apiculata \\
\hline
\end{tabular}

Tabel 1. Komposisi jenis makroalga di Pulau Sibu 


\section{Distibusi Jenis Makroalga Berdasarkan Substrat}

Distribusi makroalga paling banyak dijumpai pada substrat pasir, pasir lumpur, serta substrat karang/patahan karang. Substrat tersebut merupakan substrat yang dominan dan ditempati oleh 20 jenis makroalga yang ditemukan di lokasi penelitian. Hal tersebut berhubungan dengan kondisi serta faktor lingkungan seperti subtrat masing-masing spesies.
Adapun jenis makroalga di temukan 19 jenis yang hidup di substrat pasir, 17 jenis di substrat pasir lumpur, 8 jenis di substrat Berlumpur, 10 jenis di substrat lumpur berpasir, dan 16 jenis di subtrat karang atau patahan karang. Distribusi jenis makroalga yang di temukan di Pulau Sibu yang terlihat dari substrat atau habitat dapat dilihat pada tabel 2 berikut ini.

Tabel 2. Distibusi Jenis Makroalga Berdasarkan Substrat di Pulau Sibu

\begin{tabular}{|c|c|c|c|c|c|c|}
\hline \multirow[b]{2}{*}{ No } & \multirow[b]{2}{*}{ jenis makroalga } & \multicolumn{5}{|c|}{ Mikrohabitat } \\
\hline & & Pasir & $\begin{array}{c}\text { Pasir } \\
\text { Berlumpur }\end{array}$ & Berlumpur & $\begin{array}{l}\text { Lumpur } \\
\text { Berpasir }\end{array}$ & $\begin{array}{c}\text { Karang/ } \\
\text { Patahan Karang }\end{array}$ \\
\hline 1. & Halimeda macroloba & $\checkmark$ & $\checkmark$ & $\checkmark$ & $\checkmark$ & - \\
\hline 2. & Halimeda opuntia (forma chordata) & $\checkmark$ & $\checkmark$ & $\checkmark$ & $\checkmark$ & - \\
\hline 3. & Halimeda incrassata & $\checkmark$ & $\checkmark$ & $\checkmark$ & $\checkmark$ & - \\
\hline 4. & Halimeda opuntia (forma renschii) & $\checkmark$ & $\checkmark$ & - & $\checkmark$ & $\checkmark$ \\
\hline 5. & Chaetamorpha sp & $\checkmark$ & $\checkmark$ & - & - & $\checkmark$ \\
\hline 6. & Sargassum duplicatum & $\checkmark$ & $\checkmark$ & $\checkmark$ & $\checkmark$ & $\checkmark$ \\
\hline 7. & Sargassum polycestum & $\checkmark$ & $\checkmark$ & - & $\checkmark$ & $\checkmark$ \\
\hline 8. & Turbina ornata & $\checkmark$ & $\checkmark$ & - & - & $\checkmark$ \\
\hline 9. & Turbinaria conoides & $\checkmark$ & $\checkmark$ & - & - & $\checkmark$ \\
\hline 10. & Dictyota dichotoma & $\checkmark$ & $\checkmark$ & - & - & $\checkmark$ \\
\hline 11. & Padina australis & $\checkmark$ & $\checkmark$ & $\checkmark$ & $\checkmark$ & $\checkmark$ \\
\hline 12. & Padina boergesenii & $\checkmark$ & $\checkmark$ & $\checkmark$ & $\checkmark$ & $\checkmark$ \\
\hline 13. & Amphiroa fragilisima & $\checkmark$ & - & - & - & $\checkmark$ \\
\hline 14. & Acanthophora spicifera & $\checkmark$ & $\checkmark$ & - & - & $\checkmark$ \\
\hline 15. & Eucheuma cottoni & $\checkmark$ & - & - & - & $\checkmark$ \\
\hline 16. & Eucheuma denticulatum & $\checkmark$ & $\checkmark$ & $\checkmark$ & $\checkmark$ & $\checkmark$ \\
\hline 17. & Eucheuma spinosum & $\checkmark$ & $\checkmark$ & $\checkmark$ & $\checkmark$ & - \\
\hline 18. & Glacilaria Salicornia & $\checkmark$ & $\checkmark$ & - & - & $\checkmark$ \\
\hline 19. & Hypnea nidulans & $\checkmark$ & $\checkmark$ & - & - & $\checkmark$ \\
\hline 20. & Galaxaura apiculata (Kjellman) & - & - & - & - & $\checkmark$ \\
\hline
\end{tabular}

\section{Lebar Relung Mikrohabitat Makroalga}

jenis makroalga yang mempunyai lebar relung terlebar adalah Eucheuma denticulatum dengan nilai 0,905, dikuti oleh Halimeda opuntia formarenschii, Halimeda incrassata, Eucheuma spinosum, Halimeda macroloba, Halimeda opuntia forma chordata, Sargassum polycestum, Glacilaria Salicornia, Dictyota dichotoma, Padina australis, Padina boergesenii, Sargassum duplicatum, Turbinaria conoides, Amphiroa fragilissima,
Acanthophora spicifera, Chaetamorpha sp, Eucheuma cottoni, Hypnea nidulans, Turbinaria ornata. Sedangkan jenis makroalga dengan lebar relung tersempit yaitu Galaxaura apiculata dengan nilai 0,200 .

Hasil analisis lebar relung mikrohabitat makroalga dapat dilihat pada Tabel 3 . 
Tabel 3. Hasil Analisis Lebar Relung Mikrohabitat di Pulau Sibu

\begin{tabular}{|c|c|c|c|c|c|c|c|}
\hline \multirow[b]{2}{*}{ No } & \multirow[b]{2}{*}{ Jenis makroalga } & \multicolumn{5}{|c|}{ Proporsi } & \multirow[b]{2}{*}{$\begin{array}{l}\text { Lebar } \\
\text { relung }\end{array}$} \\
\hline & & Pasir & $\begin{array}{l}\text { Pasir } \\
\text { Lumpur }\end{array}$ & Lumpur & $\begin{array}{l}\text { Lumpur } \\
\text { Berpasir }\end{array}$ & $\begin{array}{l}\text { Karang/ } \\
\text { Patahan } \\
\text { Karang }\end{array}$ & \\
\hline 1 & Halimeda macroloba & 0,148 & 0,370 & 0,148 & 0,333 & - & 0,685 \\
\hline 2 & Halimeda opuntia forma chordata & 0,158 & 0,421 & 0,158 & 0,263 & - & 0,676 \\
\hline 3 & Halimeda incrassata & 0,178 & 0,393 & 0,161 & 0,268 & - & 0,702 \\
\hline 4 & Halimeda opuntia forma renschii & 0,209 & 0,209 & - & 0,186 & 0,395 & 0,717 \\
\hline 5 & Chaetamorpha sp & 0,200 & 0,040 & - & - & 0,760 & 0,323 \\
\hline 6 & Eucheuma cottoni & 0,250 & - & - & - & 0,750 & 0,319 \\
\hline 7 & Sargassum duplicatum & 0,232 & 0,070 & 0,047 & 0,093 & 0,652 & 0,404 \\
\hline 8 & Sargassum polycestum & 0,072 & 0,087 & 0 & 0,096 & 0,553 & 0,610 \\
\hline 9 & Turbinaria ornata & 0,113 & 0,010 & 0 & 0 & 0,788 & 0,247 \\
\hline 10 & Turbinaria conoides & 0,197 & 0,123 & 0 & 0 & 0,679 & 0,388 \\
\hline 11 & Padina australis & 0,134 & 0,104 & 0,052 & 0,075 & 0,634 & 0,461 \\
\hline 12 & Padina boergesenii & 0,195 & 0,097 & 0,029 & 0,045 & 0,634 & 0,442 \\
\hline 13 & Dictyota dichotoma & 0,158 & 0,259 & - & - & 0,556 & 0,499 \\
\hline 14 & Amphiroa fragilissima & 0,400 & - & - & - & 0,600 & 0,385 \\
\hline 15 & Acanthophora spicifera & - & 0,333 & - & - & 0,667 & 0,360 \\
\hline 16 & Eucheuma denticulatum & 0,264 & 0,191 & 0,114 & 0,285 & 0,146 & 0,905 \\
\hline 17 & Eucheuma spinosum & 0,200 & 0,400 & 0,133 & 0,267 & 0 & 0,692 \\
\hline 18 & Glacilaria Salicornia & 0,281 & 0,186 & - & - & 0,531 & 0,505 \\
\hline 19 & Hypnea nidulans & 0,192 & 0,038 & - & - & 0,769 & 0,318 \\
\hline 20 & Galaxaura apiculata & - & - & - & - & 1,000 & 0,200 \\
\hline
\end{tabular}

\section{Tumpang Tindih Relung Mikrohabitat Makroalga}

Tumpah tindih relung mikrohabit cukup besar dilakukan oleh makroalga jenis Sargassum polycestum terhadap Galaxaura apiculata sebesar 0,337 , sedangkan tumpah tindih relung sedikit atau kecil terdapat pada makroalga jenis Halimeda macroloba terhadap Galaxaura apiculata, Halimeda opuntia forma chordata terhadap Galaxaura apiculata Halimeda incrassata terhadap Galaxaura apiculata, Eucheuma spinosum terhadap Galaxaura apiculata dengan nilai 0,000 .

Hasil analisis tumpah tindih relung mikrohabitat makroalga dapat dilihat pada Tabel 4.

Tabel 4. Hasil Analisis Tumpah Tindih Relung Mikrohabitat

\begin{tabular}{|c|c|c|c|c|c|c|c|c|c|c|c|c|c|c|c|c|c|c|c|c|}
\hline Jenis & $\mathrm{Hm}$ & Hofc & $\mathrm{Hi}$ & Hof & Csp & Ec & $\mathrm{Sd}$ & $\mathrm{Sp}$ & To & Tc & $\mathrm{Pa}$ & $\mathrm{Pb}$ & $\mathrm{Dd}$ & Af & As & $\mathrm{Ed}$ & Es & Gs & $\mathrm{Hn}$ & $\mathrm{Ga}$ \\
\hline $\mathrm{Hm}$ & - & 0,197 & 0,195 & 0,116 & 0,199 & 0,253 & 0,067 & 0,051 & 0,014 & 0,120 & 0,062 & 0,058 & 0,082 & 0,040 & 0,084 & 0,152 & 0,197 & 0,076 & 0,029 & 0 \\
\hline$H o f c$ & 0,196 & - & 0,195 & 0,115 & 0,033 & 0,027 & 0,064 & 0,049 & 0,015 & 0,056 & 0,063 & 0,060 & 0,091 & 0,043 & 0,047 & 0,112 & 0,197 & 0,083 & 0,031 & 0 \\
\hline$H i$ & 0,200 & 0,203 & - & 0,119 & 0,036 & 0,031 & 0,071 & 0,051 & 0,017 & 0,059 & 0,065 & 0,063 & 0,091 & 0,050 & 0,092 & 0,152 & 0,201 & 0,086 & 0.034 & 0 \\
\hline Hof & 0,122 & 0,122 & 0,121 & - & 0,251 & 0,250 & 0,242 & 0,193 & 0,242 & 0,240 & 0,225 & 0,229 & 0,220 & 0,230 & 0,239 & 0,148 & 0,126 & 0,220 & 0,252 & 0,283 \\
\hline Csp & 0,014 & 0,016 & 0,017 & 0,113 & - & 0,200 & 0,176 & 0,142 & 0,201 & 0,181 & 0,166 & 0,169 & 0,150 & 0,173 & 0,168 & 0,055 & 0,018 & 0,151 & 0,202 & 0,245 \\
\hline$E c$ & 0,012 & 0,013 & 0,014 & 0,111 & 0,198 & - & 0,174 & 0,138 & 0,198 & 0,178 & 0,162 & 0,167 & 0,146 & 0,175 & 0,160 & 0,056 & 0,016 & 0,149 & 0,199 & 0,239 \\
\hline$S d$ & 0,040 & 0,042 & 0,041 & 0,137 & 0,220 & 0,221 & - & 0,158 & 0,218 & 0,201 & 0,186 & 0,190 & 0,169 & 0,196 & 0,185 & 0,081 & 0,043 & 0,171 & 0,222 & 0,263 \\
\hline$S p$ & 0,046 & 0,045 & 0,044 & 0,164 & 0,267 & 0,264 & 0,239 & - & 0,274 & 0,244 & 0,230 & 0,230 & 0,208 & 0,220 & 0,243 & 0,088 & 0,046 & 0,201 & 0,270 & 0,337 \\
\hline To & 0,005 & 0,005 & 0,006 & 0,083 & 0,154 & 0,153 & 0,134 & 0,110 & - & 0,138 & 0,127 & 0,129 & 0,113 & 0,128 & 0,113 & 0,036 & 0,007 & 0,112 & 0,155 & 0,195 \\
\hline$T c$ & 0,029 & 0,032 & 0,032 & 0,130 & 0,217 & 0,217 & 0,193 & 0,155 & 0,217 & - & 0,182 & 0,187 & 0,171 & 0,189 & 0,192 & 0,068 & 0,034 & 0,170 & 0,219 & 0,263 \\
\hline$P a$ & 0,046 & 0,043 & 0,048 & 0,145 & 0,236 & 0,235 & 0,213 & 0,174 & 0,238 & 0,217 & - & 0,204 & 0,185 & 0,200 & 0,211 & 0,081 & 0,044 & 0,181 & 0,238 & 0,292 \\
\hline$P b$ & 0,037 & 0,039 & 0,040 & 0,141 & 0,232 & 0,232 & 0,208 & 0,167 & 0,231 & 0,213 & 0,196 & - & 0,181 & 0,203 & 0,201 & 0,079 & 0,041 & 0,181 & 0,234 & 0,280 \\
\hline$D d$ & 0,059 & 0,067 & 0,065 & 0,153 & 0,232 & 0,228 & 0,208 & 0,170 & 0,229 & 0,220 & 0,200 & 0,204 & - & 0,198 & 0,228 & 0,086 & 0,067 & 0,194 & 0,233 & 0,277 \\
\hline Af & 0,023 & 0,024 & 0,027 & 0,123 & 0,206 & 0,212 & 0,186 & 0,139 & 0,199 & 0,187 & 0,167 & 0,176 & 0,153 & - & 0,154 & 0,074 & 0,031 & 0,166 & 0,207 & 0,231 \\
\hline As & 0,044 & 0,050 & 0,047 & 0,120 & 0,187 & 0,180 & 0,165 & 0,143 & 0,190 & 0,161 & 0,165 & 0,164 & 0,165 & 0,144 & - & 0,058 & 0,048 & 0,150 & 0,189 & 0,240 \\
\hline$E d$ & 0,200 & 0,195 & 0,196 & 0,186 & 0,155 & 0,159 & 0,183 & 0,130 & 0,133 & 0,158 & 0,093 & 0,162 & 0,156 & 0,175 & 0,146 & - & 0,200 & 0,169 & 0,154 & 0,132 \\
\hline
\end{tabular}




$\begin{array}{ccccccccccccccccccccccccccccc}\text { Es } & 0,198 & 0,202 & 0,198 & 0,121 & 0,039 & 0,035 & 0,073 & 0,052 & 0,018 & 0,061 & 0,066 & 0,065 & 0,094 & 0,055 & 0,092 & 0,153 & - & 0,090 & 0,037 & 0 \\ G s & 0,056 & 0,062 & 0,062 & 0,155 & 0,236 & 0,237 & 0,214 & 0,167 & 0,228 & 0,222 & 0,199 & 0,207 & 0,263 & 0,218 & 0,210 & 0,095 & 0,066 & - & 0,237 & 0,268 \\ H n & 0,014 & 0,015 & 0,016 & 0,112 & 0,199 & 0,199 & 0,174 & 0,141 & 0,200 & 0,180 & 0,168 & 0,168 & 0,149 & 0,171 & 0,167 & 0,054 & 0,017 & 0,149 & - & 0,245 \\ G a & 0 & 0 & 0 & 0,079 & 0,152 & 0,150 & 0,130 & 0,111 & 0,158 & 0,136 & 0,127 & 0,127 & 0,111 & 0,120 & 0,133 & 0,029 & 0 & 0,106 & 0,154 & -\end{array}$

\section{Pembahasan}

\section{Komposisi Jenis}

Komposisi jenis makroalga berhubungan erat dengan perbedaan substrat. Hal ini dipengaruhi oleh cara adaptasi makroalga terhadap tipe substrat. Berdasarkan hasil penelitian ini, tipe substrat yang ditemukan di setiap stasiun paling dominan yaitu pasir dan pecahan karang. Jenis makroalga yang ditemukan terdiri dari, jenis Halimeda, Eucheuma, Padina, Turbinaria, Dictyota, Glacilaria, Achantophora, Amphiroa, Sargassum, dan Galaxaura. Hal ini diperkuat dengan dengan hasil penelitian Liman (2001) makroalga yang tumbuh di substrat pasir kebanyakan dari marga, Halimeda, Glacilaria, Dictyota, dan Amphiroa. Sedangkan di substrat pasir karang, karang mati, karang hidup, kebanyakan ditumbuhi makroalga dari marga Acantophora, Turbinaria, Halimeda, Amphiroa, Sargassum, Valonia, dan Padina. Menurut (Handayani, 2018 ; Magrunder \& Hunt, 1979; Atmadja, 1996), Turbinaria tumbuh di daerah intertidal berbatu, rataan terumbu dan menempel pada substrat keras seperti karang hidup, karang mati maupun batuan beku. Menurut Joikel dan Morrissey (1986) Acanthophora spicifera merupakan spesies ditemukan melimpak di daerah rataan terumbu karang.

\section{Distibusi Jenis Makroalga Berdasarkan Substrat}

Berdasarkan Tabel 2, terlihat bahwa selain Galaxaura apiculata, seluruh jenis makroalga lainnya ditemukan tumbuh pada substrat Pasir. Hal ini menunjukkan bawa substrat pasir merupakan substrat yang umumnya sesuai untuk habitat makroalga, demikian pula pada substrat Pasir berlumpur hanya 3 jenis yang tidak ditemukan pada habitat tersebut yaitu Amphiroa fragilisima, Eucheuma cottoni dan Galaxaura apiculata. jenis $G$. apiculata hanya mendiami tipe substrat karang atau pecahan karang atau tidak ditemukan menempati tipe substrat yang lain.

Pada tipe substrat berlumpur, ditemukan 8 spesies, terdiri dari Halimeda macroloba, H. opuntia (forma chordata), $H$. incrassata, Sargassum duplicatum, Padina australis, P. boergesenii, Eucheuma denticulatum, E. spinosum, Hal ini menunjukkan bahwa jenis tersebut memiliki kemampuan beradaptasi dan hidup pada substrat berlumpur bila dibandingkan dengan jenis lain.

Pada substrat lumpur berpasir ditemukan sebanyak 10 jenis yaitu Halimeda macroloba, $H$. Opuntia (forma chordata), H.incrassat,. H. Opuntia (forma renschii), S. Duplicatum, S. Polycestum, Padina australis, P. Boergesenii, Eucheuma denticulatum, dan E. spinosum.

Sebanyak 16 jenis ditemukan pada tipe substrat krang atau patahan karang, dan hanya 4 jenis yang tidak dtemukan pada tipe substrat tersebut yakni jenis Halimenda macroloba, H. Opuntia (forma chordata), $H$. incrassata dan Eucheuma spinosum. Namun demikian menurut Atmadja et al (1996), genus Halimeda memiliki kemampuan adaptasi yang tinggi terhadap faktor lingkungan dan dapat tumbuh pada berbagai tipe substrat.

Sebanyak 4 jenis ditemukan pada semua tipe substrat di pulau Sibu yaitu Sargassum duplicatum, Padina australis, P. boergesenii, dan Eucheuma denticulatum. Ira (2018), menyatakan bahwa Padina australis dapat tumbuh pada berbagai substrat karena memiliki kemampuan adaptasi yang cukup tinggi. Selain itu Padina australis juga dapat tumbuh dan menempel pada pada substrat batu di rataan terumbu, baik pada tempat terbuka dan terkena hempasan ombak ataupun tertutup serta terlindung (Juneidi (2004 ; Pramesti (2009 ; Atmadja, 1998)

\section{Lebar Relung Mikrohabitat Makroalga}

Makroalga jenis Eucheuma denticulatum, Padina australis, padina boergesenii, dan Sargassum duplicatum, memiliki relung habitat terlebar, hal ini dibuktikan dari hasil pengambilan data di lapangan. Eucheuma denticulatum, ditemukan menempati 5 tipe mikrohabitat yaitu, pasir, pasir lumpur, lumpur, lumpur berpasir, dan karang/ patahan karang. Nilai lebar relung selain ditentukan dari tipe mikrohabitat (substrat), juga ditentukan oleh proporsi tiap jenis yang terdapat pada tipe mikrohabitat.

\section{Tumpang Tindih Relung Habitat}

Makrolaga jenis Galaxaura apiculata, mempunyai nilai lebar relung tersempit atau terendah karena ditemukan hanya terdapat pada 1 tipe microhabitat, yaitu pada subtrat karang/ patahan karang. Pemanfaatan relung yang sempit lebih berbahaya terhadap kelangsungan hidup populasi 
dari jenis tersebut. Lebar relung berkaitan dengan luas volume atau volume relung. Hal tersebut tergantung pada jumlah habitat. Jenis yang memiliki relung terlebar menunjukan kemampuan mengeksploitasi sumberdaya yang tersedia, baik berupa makanan, habitat, waktu dan lain sebagainya, sehingga memiliki populasi jenis yang tinggi. Kompetisi intraspesifik akan dialami oleh jenis yang memiliki relung sempit (Abubakar et al., 2018).

Hasil analisis tumpah tindih relung umumnya diperoleh hasil yang tinggi. Tingginya nilai tumpah tindih relung terjadi disebabkan kesamaan habitat masing-masing jenis. Hal tersebut menandakan bahwa terjadi kompetisi dalam hal ruang atau habitat tempat jenis itu tinggal dan makanan. Hasil analisis tumpah tindih relung juga diperoleh hasil yang renda. Hal ini terjadi karena masing-masing jenis menempati habitat yang berbeda. Hal tersebut menunjukan tidak terjadi kompetisi dimana jenis itu tinggal.

Kesaling-lingkupan relung mikrohabitat menggambarkan adanya kompetisi ruang dari dua jenis atau lebih yang memiliki relung sama yang hidup berdampingan baik dengan cara yang berbeda, jika anggota populasi makin bertambah. Kompetisi antar individu tiap jenis akan bertambah dan lebik kuat daripada kompetisi antar jenis (Abubakar et al., 2018).

Kesaling-lingkupan erat hubungannya dengan tipe asosiasi antar jenis. Pasangan jenis yang tidak memiliki asosiasi akan memikliki tumpah tinduh relung yang nilainya rendah. Sedangkan pasangan yang berasosiasi negatif memiliki nilai kasalinglingkupan atau tumpah tindih relung yang tinggi atau terjadi kompetisi dalam cara pemanfaatan sumberdaya berupa habitat, makanan atau waktu (Rondo, 2015)

Hasil pengukuran parameter lingkungan sangat menunjang terhadap pertumbuhan makroalga yang ada di Pulau Sibu. Suhu berperan penting terhadap kehidupan serta pertumbuhan makroalga. Kisaran suhu di perairan Pulau Sibu masuk dalam kriteria suhu optimum petumbuhan makroalga yaitu $31,5{ }^{\circ} \mathrm{C}$. Tingginya suhu perairan berdampak buruk bagi pertumbuhan makroalga. Hal tersebut dikarenakan peningkatan suhu dapat menyebabkan penurunan kandungan $\mathrm{O}_{2}, \mathrm{CO}_{2}, \mathrm{~N}_{2}, \mathrm{CH}_{4}$ dalam air (Haslan, 1995; Prasetyaningsi \& Rahardjo, 2016). Ambang batas suhu untuk pertumbuhan alga hijau, alga cokelat, dan alga merah yaitu $34,5^{\circ} \mathrm{C}$ (Hutagalung 1988 ; hairati et al, 2016).

Nilai salinitas berdasarkan hasil penelitan mununjukan nilai rata-rata 35 ppt. Kisaran salinitas ini dikategorikan cukup tinggi. Hal ini disebabkan rendahnya intensitas curah hujan saat penelitian. Salinitas yang baik bagi pertumbuhan makroalga brrkisar 30-34 ppt (Kadi \& Atmadja,1988 ; Prasetyaningsih \& Rahardjo, 2016). Salinitas yang terlalu tinggi atau terlalu rendah dapat menyebabkan gangguan pada proses fisiologinya (Luning, 1990 : Kurniawan 2017).

Kisaran $\mathrm{pH}$ air pada lokasi penelitian rata-rata pada kisaran 7,3. Kisara ini termasuk $\mathrm{pH}$ optimal bagipertumbuhan makroalga. Hal ini sesuai dengan yang dikemukakan oleh Setiadi et al (2000); Prasetyanimngsih \& Rahardjo, 2016 yang menyatakan $\mathrm{pH}$ yang baik dan sesuai untuk pertumbuhan makroalga berkisar antar 6-9. Kisaran $\mathrm{pH}<6$ akan menekan laju pertumbuhan makroalga, $\mathrm{pH}<9$ merupakan kisaran optimal dalam suatu perairan.

\section{Kesimpulan}

Ditemukan sebanyak 20 jenis makroalga di perairan pulau Sibu, di antaranya yaitu: Halimeda macroloba, H.opuntia forma chordate, $H$. incrassata, $H$. opuntia forma renschii, Chaetamorpha sp ,Eucheuma cottoni, Sargassum duplicatum, S. polycestum, turbinaria ornata, $T$. conoides, $P$. australis, $P$. boergesenii, Dictyota dichotoma, Amphiroa fragilissima, Acantophora spicifera, Eucheuma denticulatum, Glacilaria Salicornia, Hypnea nidulans, Galaxaura apiculata. Jenis makroalga yang memiliki relung habitat terlebar adalah Eucheuma denticulatum dan tersempit adalah Galaxaura apiculata. Tumpah tindih relung mikrohabitat yang cukup besar dilakukan oleh Sargassum polycestum terhadap Galaxaura apiculata, sedangkan tumpah tindih relung sedikit atau kecil dengan nilai yang sama terdapat pada makroalga jenis Halimeda macroloba, Halimeda opuntia forma chordata, Halimeda incrassata,Eucheuma spinosum terhadap Galaxaura apiculata.

\section{Ucapan Terima Kasih}

Terimakasih yang tak terhingga kami haturkan kepada Pemerintah dan Masyarakat Kecamatan Oba Utara yang telah banyak memfasilitas kami sehingga pelaksanaan penelitian di lapangan dapat berjalan dengan lancar. Serta seluruh personil yang mendukung terlaksananya penelitian ini, kami ucapkan terimakasih yang sebesar-besarnya.

\section{Referensi}

Atmadja, WS., A. Kadi.,Sulistijo., \& Rachmaniar (1996). Pengenalan jenis-jenis rumput laut di 
Indonesia.Pusat Penelitian dan Pengembangan Oseanologi-LIPI, Jakarta

Abubakar, S, M. Abdul kadir, n. Akbar \& I. Tahir (2018). Asosiasi Dan Relung Mikrohababitat Gastropoda Pada Ekosistem Mangrive Di pulau Sibu Kecamatan Oba Utara Kota Tidore Kepulauan Provinsi Maluku Utara. Jurnal Enggano E-ISSN: 2527-5186. PIISN:2615-5958, 3 (1), April 2018. Hlm : 2238.

Afrianto, E \& Liviawati, E. (1993). Budidaya Rumput Laut dan Cara Pengolahannya. Penerbit Bhratara, Jakarta.

Anggadiredja, T. Jana. (2009). Rumput Laut ; Pembudidayaan, Pengolahan, \& Pemasaran Komoditas Perikanan Potensial. Depok : Penebar Swadaya

Anonimous (2008). Algacoklat.(Online)" Alga Cokelat http://id.wikipedia.org/wiki. Diakses Tanggal 11 november 2008.

Bold, H.C. \& M.J. Wynne (1985). Introduction to the Algae. USA: Prentice Hall Inc. Eaglewood Cliffs. New Jersey, 720 hal.

Dawes, C.J. (1998), Marine Botany, 2nd Ed., A Wiley-Interscience Publication, New York.

D. R. H. Kumampung, B. Soeroto. R. Ch. Kepel. F. Losung. F. Manajang \& J. M. Mamuja (2006). Pola Reproduksi Kandungan Agar dan Kekuatan Gel pada Alga Merah Glacilaria salicornia(C. Agardh) Dawson dari Pantai 41 Malalayang. Journal of Research and Development Sam Ratulangi University. 29 (1), p; Hal: 79-184

Hairati, Arfah, \& Patty, S. (2016). Kualitas Air dan Komunitas Makroalga di Perairan Pantai Jikumerasa, Pulau Buru. Jurnal Ilmiah Plantax, 4(2), 109-119.

Handayani T. (2018). Mengenal Makroalga Turbinaria Dan Pemanfaatannya. Jurnal Oseana. XLIII (4). Hal. 28-39.

Ira (2018). Struktur Komunitas Makro Alga di Perairan Desa Mata Sulawesi Tenggara. Jurnal Biologi Tropis. 18 (1). Hal. 45-56.
Ismail, A. (1995). Rumput Laut Malaysia. Percetakan Dewan Bahas dan Pustaka Lot. 1037. Malaysia.

Juana, K. R. S. (2009). Biologi Laut: Ilmu Pengetahuan Tenteng Biota Laut. Jakarta. Djambatan.

Junaedi, W. A. (2004). Rumput Laut, Jenis dan Morfologinya. Departemen Pendidikan dan Kebudayaan. Nabire.

Kadi, A. (2004). Potensi Rumput Laut dibeberapa Perairan Pantai Indonesia. JurnalOseana. XXIX: 25-36

Kadi \& Atmadja (1988). Prasetyaningsih \& Rahardjo, 2016

Kendeigh S. C. (1980). Ecology with Special Animal and man. Prentice Hall of India. New Delhi.

Kurniawan, R. (2017). Keanekagaragaman Jenis Makroalga diPerairan Laut DesaTeluk Bakau Kabupaten Bintan Riau. Skripsi. Fakultas Ilmu Kelautan dan Perikanan. Universitas Tamaritim Ali Haji TanjungPinang. Hal 1-62.

Lobban, C.S., \& Wynne, M.J. (1981). The Biology of Seaweeds. Volume 17. Oxford London: Blackwell Scientific Publications. Halaman 357.

Liman, D. (2001). Copetition Between Macroalgae and Corals: Effect of Herbivore Exclusion and Increased Algae Biomass on Coral Survivorship and Growth. Springer, New york. Pp.392-399.

Luning, K. (1990). Seawed :Their environment, biogeography, and ecophysiology. John Wiley and Sonc Inc. Canada.

Magrunder W. H. and J. W. Hunt. 1979. Seaweeds of Hawaii. Oriental Publising Company. 116 pp

Michael, P. (1984). Ecological System Method for File and LaboratoryInvestigation. New Delhi: Tata Mcgraw-Hill Publishing Company Limited.

M, Putri (2018). Studi Ekologi Hutan Mangrove di Pulau Sibu Kecamatan Oba Utara Kota Tidore Kepulauan. Skripsi. Universitas Khairun Ternate. Ternate 
Odum (1971). Fundamental Ecology. Universitas Gajah Mada Press. Yogyakarta

Pallalo A. (2013). Distribusi Makroalga pada Ekosistem Lamun dan Terumbu Karang di Pulau Bonebatang Kecamatan Ujung Tanah Kelurahan Barang Lampo. Universitas Hasanuddin. Makassar.

Pipit Marianingsih. Evi A \& Teguh S. (2013) Inventarisasi dan Identifikasi Makroalga di Perairan Pantai Pulau Untung Jaa. Jurnal Program Studi pendidikan Biologi, FKIPUNTIRTA, Prosiding Semirata FMIPA Universitas Lampung.

Pusputasari Tiara Ariyanto (2011). Keanekaragaman dan Kelimpahan Echinodermata di Pulau Barang Lampo Kecamatan Ujung Tanah Kota Makassar. Skripsi. Makassar. Fakultas Sains dan Teknologi UIN Alauddin.

Prasetyaningsih, A. \& Rahardjo, D. (2016). Keanekaragaman dan Biodiversitas Senyawa Aktif Makroalga Pantai Wadiombo Kabupaten Gunung Kidul. Jural Agrisains, 17 (1), 107-115.

Rondo, M. (2015). Metodologi Analisis Ekologi Populasi dan Komunitas Biota Perairan. Program Pascasarjana. Unstrat. Manado.

Salvador Neomi, Amelia Gomez Garreta, Luca Lavell, \& Maria Antonia Ribera (2007). Antimicrobial activity of Iberian Macroalgae. IBERIAN: Universitat de Barcelona.
Setiadi (2000). Rumput Laut Komoditas Unggulan. Grasindo. Jakarta

Sulisetijono (2000). Studi Eksplorasi Potensi dan Taksonomi Makroalga di Pantai Kondang Merak Kabupaten Malang : Lembaga Penelitan Universitas Negeri Malang.

Sulisetijono (2009). Bahan Serahan Alga. Malang: UIN Malang

Tjitrosoepomo, G. (1998). Taksonomi Tumbuhan. Yogyakarta: UGM Press

Vahita. B.R. (1984). Algae. Schand and Company Ltd. Ramnager. New Delhi.

Waryono T. (2001). Biogeografi Alga Makro (Rumput Laut) di Kawasan Pesisir Indonesia. Kumpulan Makalah Periode 1987-2008.

Yudasmara, A. (2011). Analisis Komunitas Makroalga Di Perairan Pulau Menjangan Kawasan Taman Nasional Bali Barat. Jurnal Sains dan Teknologi, 11. WIDYATECH

Yulianto, K. (1996). Keberadaan Fikokoloid Alginat dalam Makroalga Coklat. Balitbang Sumberdaya Laut, Puslitbang Oseanologi. LIPI. Ambon: Lonawarta. XIX (1)

Yulianda, F, M. Yusuf \& W. Prayogo (2013). Zonasi dan Kepadatan Komunitas Intertidal di Daerah Pasang Surut, Pesisir Batuhijau, Sumbawa. Jurnal Ilmu dan Teknologi Kelautan Tropis, 5 (2), Hlm. 409-416, Desember 2013. 